\title{
Technologies applied to sorghum (Sorghum bicolor L. Moench): changes in phenolic compounds and antioxidant capacity
}

\author{
Norma Julieta SALAZAR-LÓPEZ, Gustavo GONZÁLEZ-AGUILAR², Ofelia ROUZAUD-SÁNDEZ", \\ Maribel ROBLES-SÁNCHEZ ${ }^{1 *}$
}

\begin{abstract}
The search for foods with biological potential for the prevention of chronic diseases has highlighted sorghum, and numerous studies have been conducted to determine the best processing conditions without compromising the nutritional, functional or sensory qualities. We conducted a review of the scientific literature on the techniques used in sorghum and their effects on phenolic compounds and antioxidant capacity. This review allowed us to conclude that the type and content of phenolic compounds in the different varieties of sorghum must be considered for the selection of adequate technologies that allow the retention of phenolic compounds with improved bioaccessibility and biological potential. The available information has been mostly focused on the content of total phenols and the antioxidant activity of sorghum, while the digestibility, absorption, utilization and excretion of phenolic compounds have been poorly studied. In this regard, there is a clear need for further studies on sorghum with the aim of including sorghum as part of a healthy diet.
\end{abstract}

Keywords: sorghum; technological processes; antioxidant capacity; phenolic compounds.

Practical Application: Impact of processing sorghum on the retention the phenolic compounds and antioxidant capacity.

\section{Introduction}

Sorghum is the fifth most-produced cereal in the world after corn, rice, wheat and barley being, USA, Mexico, Nigeria, Sudan and India the major producers, contributing with 16\%, $12.2 \%, 9.8 \%, 9.1 \%$ and $7.8 \%$ and of total world production, respectively (Food and Agriculture Organization Corporate Statistical Database, 2017).

Sorghum is a source of carbohydrates $(60-70 \%)$, proteins (8-12\%), oil (2.8-3.6\%), fiber (approximately $8 \%)$, ash (1-2\%), vitamins and phytochemicals, such as phytosterols, policosanols, carotenoids and phenolic compounds, including flavonoids, tannins, anthocyanins, among others, which contribute its biological potential (Cardoso et al., 2014; Chávez et al., 2017; Llopart \& Drago, 2016; Stefoska-Needham et al., 2015).

Epidemiological studies have associated the consumption of sorghum with a reduction in the incidence of gastrointestinal cancer (Stefoska-Needham et al., 2015; Yang et al., 2012). The intake of sorghum could also contribute to the control of diabetes because the cereal reduces glucose and insulin responses in men compared with wheat (Poquette et al., 2014). This protective effect has been attributed to some constituents of sorghum that are involved in the inhibition or reduction of oxidative stress and inflammatory, mutagenic and carcinogenic processes, and these biological activities have been associated with the presence of phytochemicals, particularly phenolic compounds (Anunciação et al., 2017; Lin et al., 2013; Mošovská et al., 2010; Nguyen et al., 2015; Poquette et al., 2014; Yang et al., 2012;
Cardoso et al., 2017). However, it is very important to consider that there are other compounds in sorghum that can affect its biological potential (Cardoso et al., 2017).

Phenolic compounds extracted from whole grains and from the cellular walls of red and white sorghum inhibited the oxidation of low-density lipoproteins and protected DNA against oxidative damage, which could be helpful in the prevention of cardiovascular diseases mediated by oxidative stress (Salawu et al., 2014). Some compounds isolated from sorghum bicolor, such as methyl 3,4-dihydroxybenzoate, 3,4,5-trihydroxycinnamate, methyl 3,4-dihydroxycinnamate, caffeoyl glycolic acid methyl ester and 1-O-caffeoylglycerol, showed inhibitory potential on nitric oxide production and reduction of the expression of iNOS with a dose-dependent effect on macrophage RAW264.7 induced with lipopolysaccharide (E. coli). Furthermore, the compounds methyl 3,4-dihydroxybenzoate (2,3,4,5-trihydroxycinnamate and methyl 3,4-dihydroxycinnamate significantly suppressed LPS-induced COX-2 protein expression (Nguyen et al., 2015). Black and white sorghum extracts may be protective against colon cancer through their estrogenic activity, which reduced cell growth via induction of apoptosis. The presence of flavones in sorghum extract, such as luteolin, apigenin and their O-methyl derivatives, which have estrogenic properties, could be responsible for the protective effect against colon cancer (Yang et al., 2012). Nevertheless, the aforementioned biological potential of sorghum could be modified to a great extent due to different technologies 
applied before its intake (Chávez et al., 2017). This review was conducted to obtain a better understanding of the effects of the application of different treatments on sorghum and its products, examining the most important works that have focused on the use of technologies for preserving and improving the content of total phenols and the biological activity of sorghum.

\section{Phenolic compounds in sorghum grains}

The structural diversity of phenolic compounds results in a wide range of phenolic compounds that occur in nature. These compounds can generally be categorized into several classes: flavonoids, tannins and phenolic acids. Table 1 shows the total phenol contents of sorghum and cereals with greater consumption; the variability in phenolic content is mainly attributed to the variety and type of cereal, the part of the grain tested and the extraction method. The extraction solvent becomes a key factor in the quantification of total phenols; before selecting an extraction system, it is very important to have knowledge of the composition of the food matrix to reduce the possibility of over- or underestimation of the content of total phenols (Tiwari et al., 2011).

Sorghum is a source of phenolic acids, phenolic acid glyceride esters (caffeoyl glycerols), flavonoids (flavanones, flavonols, flavanonols and flavan-3-ol derivatives), phenylpropane glycerides, dicaffeoyl spermidine and condensed tannins (flavan-3-ols and/or flavan-3,4-diols) (Kang et al., 2016; Yang et al., 2012; Zaroug et al., 2014). The main structures of the phenolic compounds in sorghum are shown in Figure 1.
Phenolic acids found in sorghum can in turn be classified as derivatives of benzoic acid (gallic, $\rho$-hydroxybenzoic, syringic and protocatechuic acids) or derivatives of cinnamic acid ( $\rho$-coumaric, caffeic, chlorogenic, ferulic and sinapic acids) (Luthria \& Liu, 2013).

Flavonoids in sorghum consist mainly of 3-deoxyanthocyanidins, although it is also possible to find flavones and flavanones. In sorghum with black and brown pericarp, the major proportion of flavonoids are highly accessible because approximately $80 \%$ are found in the free form, while in sorghum with red and white pericarp, the proportion of free flavonoids is $26-41 \%$ and $26 \%$, respectively (Wu et al., 2017). Sorghum with black pericarp is a source of 3-deoxyanthocyanidins, mainly in the free form, while brown pericarp is a source of flavones, dihydroflavonol and flavanone in the free form (Wu et al., 2017).

Structurally, the tannins found in sorghum are oligomers or polymers of phenolic compounds; they are heterogeneous molecules generally composed of flavan-3-ol and flavan 3,4-diols, which have the capacity to establish interactions with proteins, carbohydrates, lipids, and metals (Awika \& Rooney, 2004; Jakobek, 2015; Domínguez-Avila et al., 2017). Tannins are found in sorghum with pigmented testa and a chalky red, chalky brownish-red or black appearance in concentrations between 10 and $68 \mathrm{mg} / \mathrm{g}$ (Awika \& Rooney, 2004; Dykes et al., 2014; Dykes et al., 2005).

In sorghum, as in other cereals, phenolic compounds are concentrated in the outer layers of the grain (aleurone, testa and pericarp), where it is possible to find more than $90 \%$ of the

Table 1. Total phenolic contents in sorghum and cereals of greater consumption.

\begin{tabular}{|c|c|c|c|}
\hline Cereal & Food matrix & Extraction method & Total phenols \\
\hline \multirow[t]{10}{*}{ Sorghum } & Tannin grain & Acidified methanol & $16.5-29.6^{2}$ \\
\hline & Non-tannin black grain & Acidified methanol & $18.2^{2}$ \\
\hline & Non-tannin red grain & Acidified methanol & $11.8^{2}$ \\
\hline & Non-tannin white grain & Acidified methanol & $8.1^{2}$ \\
\hline & Red grain & Aqueous acetone-methanol extraction & $5.0^{1}-7.3^{4}$ \\
\hline & White grain & Aqueous acetone extract & $1.0^{1}$ \\
\hline & Red bran & Aqueous acetone-ethanol extraction & $20.0^{1}-62.5^{3}$ \\
\hline & Black bran & Ethanol extraction & $23.4^{3}$ \\
\hline & Brown bran & Ethanol extraction & $7.0^{3}$ \\
\hline & White bran & Ethanol aqueous acetone extraction & $3.1^{3}-5.0^{1}$ \\
\hline \multirow[t]{4}{*}{ Rice } & Black grain & Methanol extraction & $3.1^{4}$ \\
\hline & Whole grain & Methanol extraction & $0.5^{4}$ \\
\hline & White grain & Methanol extraction & $0.2^{4}$ \\
\hline & Bran & Ethanol extraction & $6.0^{3}$ \\
\hline Wheat & Bran & Ethanol extraction & $3.9^{3}$ \\
\hline Barley & Grain & Methanol extraction & $0.5^{4}$ \\
\hline Oat & Bran & Ethanol extraction & $0.8^{3}$ \\
\hline \multirow[t]{4}{*}{ Corn } & Black grain & Ethanol extraction + alkaline hydrolysis & $4.6^{5}$ \\
\hline & Yellow grain & Ethanol extraction + alkaline hydrolysis & $5.5^{5}$ \\
\hline & Blue grain & Ethanol extraction + alkaline hydrolysis & $3.4^{5}$ \\
\hline & White grain & Ethanol extraction + alkaline hydrolysis & $1.7^{5}$ \\
\hline
\end{tabular}

${ }^{1}$ Awika et al. (2003); ${ }^{2}$ Awika et al. (2009); ${ }^{3}$ Burdette et al. (2010); ${ }^{4}$ Choi et al. (2007); ${ }^{5}$ Lopez-Martinez et al. (2009). Total phenolic content was determined using the Folin-Ciocalteu method and expressed as mg equivalent of gallic acid/g (mg GAE/g). Total phenols (free+bound): Ethanol extraction+alkaline hydrolysis. 


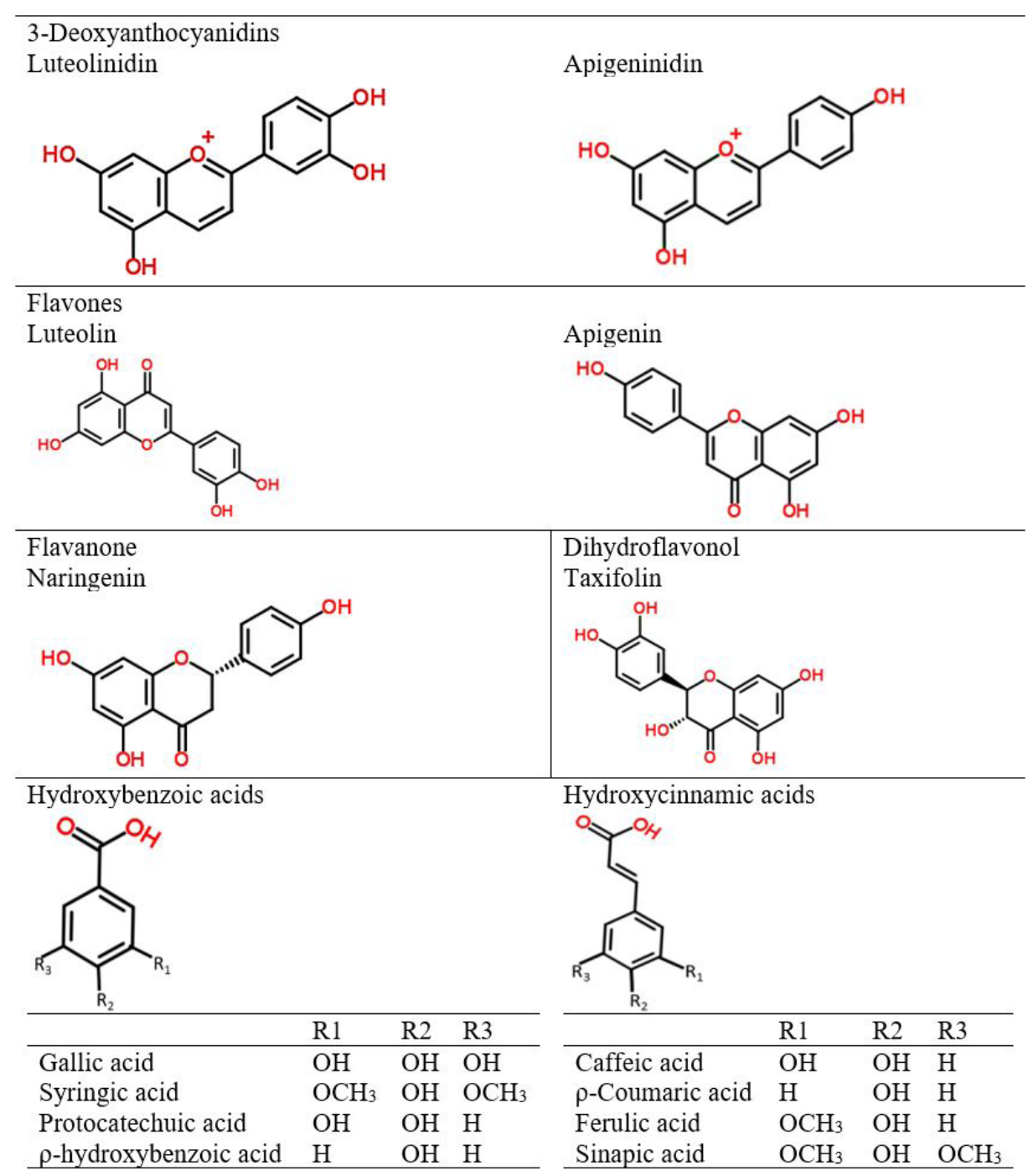

Figure 1. Main structures of the phenolic compounds founded in sorghum grain (Cardoso et al., 2017; Wu et al., 2017).

total content of phenolic compounds. The phenolic compounds are found in the free and conjugated forms (soluble in organic solvents) or bound (non-soluble in organic solvents) mainly to carbohydrates, which requires acid or alkaline hydrolysis for its extraction (Acosta-Estrada et al., 2014; Chávez et al. 2017; Morales Ortega et al., 2013). The structural localization of phenolic compounds affects their metabolism and absorption. The free phenolic compounds and oligomers of low molecular weight (ferulated and procyanidin oligomers) are accessible to be absorbed in the small intestine, but the bound phenolic compounds have low bioaccessibility, and a large proportion of them can only be metabolized by colon microorganisms (Ayala-Soto et al., 2015; Domínguez-Avila et al., 2017).

In sorghum, the content of phenolic compounds is a function of the variety, genotype, color pericarp and the presence of testa and whether it is pigmented or unpigmented. The environmental and irrigation levels during crop growth, as well as the extraction method and quantification method used determine the phenolic compound content (Awika et al., 2009;
Dykes et al., 2013; Wu et al., 2017). Table 2 shows a list of the main phenolic compounds in sorghum and Figure 2 shows the contents of phenolic acids in cereals of greater consumption, and it is possible to observe that the phenolic acid content from sorghum is larger in cereals, such as rice, oat and barley. It is a common characteristic of cereals to have a larger proportion of hydroxycinnamic acids than hydroxybenzoic acids. This is in agreement with the findings of Chiremba et al. (2012), who reported higher contents of phenolic acids and total phenols in hard sorghum bran than in soft sorghum cultivars; they also reported that the proportion of hydroxycinnamic acids in bran was higher than that of hydroxybenzoic acids. Guo \& Beta (2013) evaluated the content of phenolic acids in sorghum and other cereals and found that the highest proportion corresponded to ferulic acid. Other authors have reported the presence of phenolic acids that included phenolic acid derivatives, aldehyde and ester of glycerol (Svensson et al., 2010; Yang et al., 2012), or dimers and trimers of ferulic acid (Ayala-Soto et al., 2015). 
Table 2. Phenolic compounds and antioxidant capacity from free and bound extracts of different sorghum varieties.

\begin{tabular}{|c|c|c|c|c|c|c|c|c|}
\hline & \multicolumn{2}{|c|}{ Black pericarp } & \multicolumn{2}{|c|}{ Brown pericarp } & \multicolumn{2}{|c|}{ Red pericarp } & \multicolumn{2}{|c|}{ White pericarp } \\
\hline & Free & Bound & Free & Bound & Free & Bound & Free & Bound \\
\hline Total phenols & $<19.8^{1}$ & $2.7 \pm 0.0$ & $10.4 \pm 0.1$ & $1.7 \pm 0.1$ & $1.5-2.1$ & $1.9-2.2$ & $1.0 \pm 0.0$ & $0.8 \pm 0.1$ \\
\hline Total flavonoids & $5.2 \pm 0.1$ & $1.2 \pm 0.1$ & $4.4 \pm 0.2$ & $0.85 \pm 0.0$ & $0.3-0.5$ & $0.9-1.2$ & $0.04 \pm 0.0$ & $0.1 \pm 0.0$ \\
\hline Condensed tannins & \multicolumn{2}{|c|}{$<48.7^{1}$} & \multicolumn{2}{|c|}{$13.2 \pm 0.1^{2}$} & \multicolumn{2}{|c|}{$2.0 \pm 0.0^{2}$} & \multicolumn{2}{|c|}{$0.6 \pm 0.0^{2}$} \\
\hline \multicolumn{9}{|c|}{ Phenolic acids $(\mu \mathrm{g} / \mathrm{g})$} \\
\hline Caffeic acid & $35.6 \pm 0.8$ & $15.8 \pm 0.3$ & $14.8-20.1^{3}$ & $30.9^{3 *}-35.7$ & $10.4-11.0$ & $20.6 \pm 1.1^{4 *}$ & $13.4 \pm 0.1$ & $3.8 \pm 0.2$ \\
\hline Ferulic acid & $19.8 \pm 1.7$ & $128.6 \pm 3.3$ & $4.6^{3}-17.2$ & $117.0-706.9^{3 *}$ & $7-13$ & $48.7-60.3$ & $3.5 \pm 0.1$ & $39.4 \pm 0.2$ \\
\hline$p$-Coumaric acid & & & $0.8-2.3^{3}$ & $47.7-60.0^{3 *}$ & $34.6 \pm 2.1^{4}$ & $72.8 \pm 3.2^{4 \star}$ & & \\
\hline$o$-Coumaric acid & & & $0.7^{3}$ & $1.0-7.6^{3 *}$ & & & & \\
\hline Sinapic acid & & & $13.7-14.5^{3}$ & $7.8-14.3^{3 *}$ & & & & \\
\hline Vanillic acid & & & $3-1-5.8^{3}$ & $24.3-36.1^{3 *}$ & $25.1 \pm 1.6^{4}$ & $\mathrm{ND}^{4 *}$ & & \\
\hline Gallic acid & & & $1.8^{3}$ & $16.6-32.7^{3 *}$ & & & & \\
\hline Chlorogenic acid & & & $15.7-31.2^{3}$ & $\mathrm{ND}^{3 *}$ & & & & \\
\hline Syringic acid & & & $1.0-3.0^{3}$ & $7.5-8.9^{3 *}$ & & & & \\
\hline \multicolumn{9}{|c|}{ 3-Deoxyanthocyanidins $(\mu \mathrm{g} / \mathrm{g})$} \\
\hline Luteolinidin & $9-390^{1}$ & $0.9 \pm 0.0$ & $1.8 \pm 0.1$ & $1.1 \pm 0.1$ & $1.3-4.4$ & $<0.9$ & ND & ND \\
\hline Apigeninidin & $8.87-376^{1}$ & $0.5 \pm 0.1$ & $5.4 \pm 0.1$ & $2.4 \pm 0.0$ & $1.4-4.1$ & $1.2 \pm 0.0$ & ND & ND \\
\hline \multicolumn{9}{|c|}{ Flavones $(\mu \mathrm{g} / \mathrm{g})$} \\
\hline Luteolin & $3.3 \pm 0.2$ & ND & $6.8 \pm 0.2$ & $15.9 \pm 0.1$ & $0.8-0.9$ & $<3.1$ & ND & ND \\
\hline Apigenin & $3.7 \pm 0.1$ & $3.9 \pm 0.2$ & $1.4 \pm 0.1$ & $13.5 \pm 0.3$ & $0.2-0.7$ & $0.7-2.6$ & $\mathrm{ND}$ & ND \\
\hline \multicolumn{9}{|c|}{ Flavanone $(\mu \mathrm{g} / \mathrm{g})$} \\
\hline Naringenin & $4.9-53.1^{1}$ & $8.0 \pm 0.1$ & $5.4 \pm 0.1$ & $1.8 \pm 0.1$ & $0.2-0.4$ & $1.8-3.3$ & ND & ND \\
\hline \multicolumn{9}{|c|}{ Antioxidant Capacity } \\
\hline DPPH & $25.5 \pm 0.5$ & $4.2 \pm 0.1$ & $21.9 \pm 0.3$ & $2.1 \pm 0.0$ & $1.1-1.8$ & $2.5-3.0$ & $0.4 \pm 0.1$ & $0.9 \pm 0.1$ \\
\hline
\end{tabular}

Data were obtained from Wu et al. 2017, except those with superscripts: ${ }^{1}$ Dykes et al. (2013); ${ }^{2}$ Vargas-Solórzano et al. (2014); ${ }^{3}$ Chávez et al. (2017); ${ }^{4}$ Wu et al. (2013). Free phenol compounds were extracted with $80 \%(\mathrm{v} / \mathrm{v})$ aqueous methanol; bound phenol compounds were extracted by acid hydrolysis $(2 \mathrm{M} \mathrm{HCl}) .{ }^{*}$ Bound phenol compounds were extracted with alkaline hydrolysis; ND, not detected. Total phenols (mg GAE/g); Total Flavonoids (mg CE/g); Condensed tannins (mg CE/g); DPPH (mg TE/g).

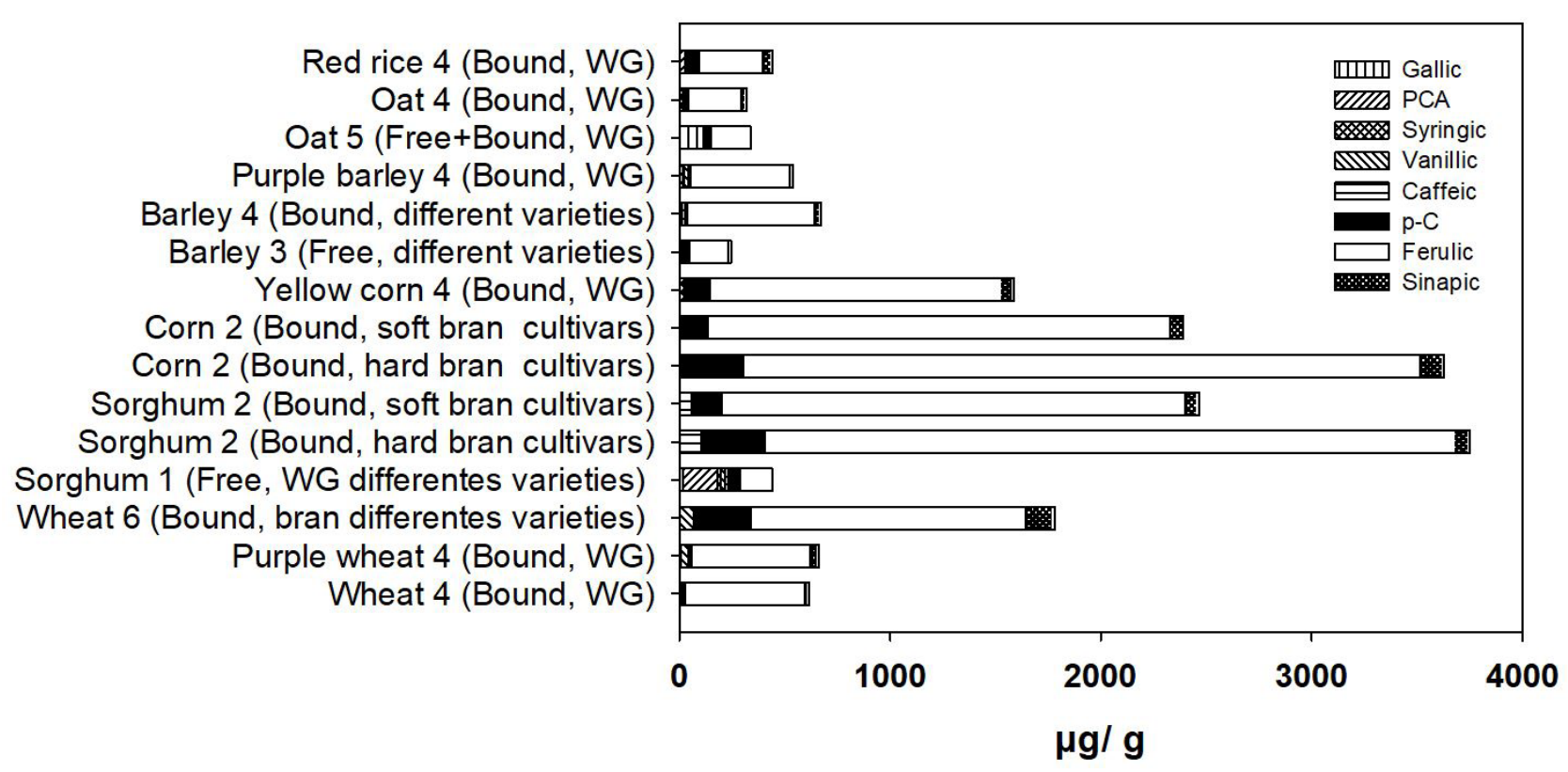

Figure 2. Contents of hydroxybenzoic and hydroxycinnamic acids in cereals of greater consumption. The information in parentheses indicates the type of phenolic extract, alcohol-extractable phenols (free) and phenols extractable by alkaline hydrolysis (bound); and the part of the plant tested, whole grain (WG) and bran. Abbreviations: PCA (protocatechuic acid); $\rho$-C ( $\rho$-coumaric acid). The number are the references: (1) Afify et al. (2012); (2) Chiremba et al. (2012); (3) Dvořáková et al. (2008); (4) Guo \& Beta (2013); (5) Xu et al. (2009); (6) Verma et al. (2009). 


\section{Effects of processing of sorghum on the contents of phenolic compounds}

Although sorghum is rich source of phenolic compounds, their bioaccessibility may be affected by the technologies or processes applied before their intake, which may interfere in their biological potential. The following is a summary of the main procedures applied in sorghum and their effects on phenolic compounds and antioxidant capacity (Table 3 ).

\section{Precooking}

Due to the hardness of sorghum, it must be processed prior to cooking. Processes such as milling, decortication and soaking are commonly applied to sorghum grain. The grinding of whole grains produces whole-meal flour, in which all components maintain their original proportions; this procedure alters the physical structure of the grains, increasing their surface area, which potentially increases the extractability of their chemical constituents.

Table 3. Effects of different technological process on total phenolic content (TPC) and antioxidant capacity (AOX) of sorghum.

\begin{tabular}{|c|c|c|c|c|}
\hline Matrix & Technological Processes & TPC (\%) & $\operatorname{AOX}(\%)$ & Reference \\
\hline \multicolumn{5}{|c|}{ SOAKING } \\
\hline Red sorghum & Soaking $1 \mathrm{~h} / \mathrm{dried}$ at $50^{\circ} \mathrm{C}$ & $\downarrow 38.8$ & $\downarrow 20.8$ & Wu et al. (2013) \\
\hline White sorghum (Dorado) & Soaking $20 \mathrm{~h}$ (water discarded) & $\downarrow 35.4$ & $\downarrow 19.2$ & Afify et al. (2012) \\
\hline White sorghum (Shandawell) & Soaking $20 \mathrm{~h}$ (water discarded) & $\downarrow 40.0$ & $\downarrow 13.1$ & Afify et al. (2012) \\
\hline White sorghum (Giza) & Soaking $20 \mathrm{~h}$ (water discarded) & $\downarrow 43.9$ & $\downarrow 14.5$ & Afify et al. (2012) \\
\hline \multicolumn{5}{|c|}{ WET HEAT } \\
\hline Tannin sorghum & Soaking/Boiling $10 \mathrm{~min}$ & $\downarrow 33.4$ & & Towo et al. (2006) \\
\hline Sorghum with non-pigmented testa & Cooking by boiling $100^{\circ} \mathrm{C} 12 \mathrm{~min}$ & $\downarrow 45.2$ & $\downarrow 51.7$ & N’Dri et al. (2013) \\
\hline Red non-tannin sorghum flour & Boiling $100^{\circ} \mathrm{C} 25 \mathrm{~min} / \mathrm{drying} / \mathrm{milling}$ & $\downarrow 27.6$ & $\downarrow 10.6$ & Cardoso et al. (2014) \\
\hline Red sorghum & Steaming $200-220^{\circ} \mathrm{C}, 20 \mathrm{~min} / \mathrm{dried} 50^{\circ} \mathrm{C}$ & $\downarrow 20.7$ & $\downarrow 31.5$ & Wu et al. (2013) \\
\hline Sorghum & Open-pan boiling (10 min) & $\downarrow 42.8$ & & Hithamani \& Srinivasan (2014) \\
\hline \multirow{2}{*}{\multicolumn{5}{|c|}{ DRY HEAT }} \\
\hline & & & & \\
\hline Brown sorghum (with PRA \& rich 3 DXA) & Dry heat $121^{\circ} \mathrm{C} / 25 \min (\mathrm{CO})$ & $\downarrow 8.3$ & $\uparrow 16.6$ & Cardoso et al. (2015) \\
\hline Red sorghum (rich 3-DXA \& without PRA) & Dry heat $121^{\circ} \mathrm{C} / 25 \mathrm{~min}(\mathrm{CO})$ & $\uparrow 5.7$ & $\uparrow 14.6$ & Cardoso et al. (2015) \\
\hline Red non-tannin sorghum flour & Oven $121^{\circ} \mathrm{C}, 25 \mathrm{~min} / \mathrm{milling}$ & $\uparrow 1.7$ & $\uparrow 8$ & Cardoso et al. (2014) \\
\hline Red sorghum & Roasting $150^{\circ} \mathrm{C}, 1 \mathrm{~h} /$ dried $50^{\circ} \mathrm{C}$ & $\uparrow 19.9$ & $\uparrow 16.8$ & Wu et al. (2013) \\
\hline \multirow[t]{2}{*}{ Sorghum } & Cooking by roasting $\left(150^{\circ} \mathrm{C}, 5 \mathrm{~min}\right)$ & $\uparrow 49.1$ & & Hithamani \& Srinivasan (2014) \\
\hline & \multicolumn{4}{|l|}{ EXTRUSION } \\
\hline Brown with tannin & Extrusion $60-140^{\circ} \mathrm{C} /<20 \%$ moisture & $\downarrow 40$ & $\downarrow 56.7$ & (Chávez et al. 2017) \\
\hline Brown without tannin & Extrusion $60-140^{\circ} \mathrm{C} /<20 \%$ moisture & $\downarrow 10.8$ & $\downarrow 27$ & (Chávez et al. 2017) \\
\hline White sorghum bran & Extrusion $180^{\circ} \mathrm{C} / 20 \%$ moisture & $\uparrow 52$ & $\uparrow 53.1$ & (Salazar Lopez et al., 2016) \\
\hline Non-tannin / tannin sorghum & Extrusion $150 \& 160^{\circ} \mathrm{C} / 30-90 \mathrm{~s}$ & $\downarrow 56.6 / \downarrow 70.1$ & $\downarrow 76.9 / \downarrow 84.9$ & Dlamini et al. (2007) \\
\hline DG non-tannin/ tannin sorghum & Extrusion $150 \& 160^{\circ} \mathrm{C} / 30-90 \mathrm{~s}$ & $\uparrow 70.0 / \downarrow 12.8$ & $\uparrow 157.1 / \downarrow 55.1$ & Dlamini et al. (2007) \\
\hline Brown sorghum (with PRA \& rich 3 DXA) & Extrusion cooking $150^{\circ} \mathrm{C}$ & $\downarrow 20.0$ & $\uparrow 0.7$ & Cardoso et al. (2015) \\
\hline Yellow sorghum (low 3 DXA \& without PRA) & Extrusion cooking $150^{\circ} \mathrm{C}$ & $\downarrow 13.6$ & $\downarrow 10.5$ & Cardoso et al. (2015) \\
\hline Red sorghum (rich 3-DXA \& without PRA) & Extrusion cooking at $150^{\circ} \mathrm{C}$ & $\downarrow 14.3$ & $\downarrow 8.8$ & Cardoso et al. (2015) \\
\hline \multicolumn{5}{|c|}{ FERMENTATION } \\
\hline Non-tannin sorghum (NK 283) & Fermented slurry/porridge & $\downarrow 47.2 / \downarrow 17.0$ & $\downarrow 51.9 / \downarrow 61.5$ & Dlamini et al. (2007) \\
\hline Tannin sorghum (NS 5511) & Fermented slurry/porridge & $\downarrow 54.9 / \downarrow 59.4$ & $\downarrow 61.7 / \downarrow 80.7$ & Dlamini et al. (2007) \\
\hline DG non-tannin sorghum (NK 283) & Fermented slurry/porridge & $\uparrow 30.0 / \uparrow 50.0$ & $\downarrow 57.1 / \downarrow 42.9$ & Dlamini et al. (2007) \\
\hline DG tannin sorghum (NS 5511) & Fermented slurry/porridge & $\uparrow 10.6 / \downarrow 23.4$ & $\downarrow 59.2 / \downarrow 73.5$ & Dlamini et al. (2007) \\
\hline Flour of whole-tannin sorghum & Soaking/boiling/fermentation & $\downarrow 48.9$ & & Towo et al. (2006) \\
\hline Low-tannin sorghum (Tabat) & Fermentation 8 h/24 h (Ajin) & $\downarrow 7.5 / \uparrow 60.4$ & $\uparrow 15.8 / \uparrow 185.3$ & Zaroug et al. (2014) \\
\hline High-tannin sorghum (Wad Ahmed) & Fermentation 8 h/24 h (Ajin) & $\uparrow 1.5 / \downarrow 11.5$ & $\uparrow 45.0 / \uparrow 26.5$ & Zaroug et al. (2014) \\
\hline Low-tannin sorghum (Tabat) & Fermentation baking $8 \mathrm{~h} / 24 \mathrm{~h}$ (kisra) & $\uparrow 43.4 / \uparrow 43.4$ & $\uparrow 176.2 / \uparrow 150.0$ & Zaroug et al. (2014) \\
\hline High-tannin sorghum (Wad Ahmed) & Fermentation baking 8 h/ 24 h (kisra) & $\uparrow 9.1 / \uparrow 13.6$ & $\uparrow 90.9 / \uparrow 139.1$ & Zaroug et al. (2014) \\
\hline \multirow[t]{2}{*}{ Sorghum/whole grain } & Sprouting & $\uparrow 5.4$ & & Hithamani \& Srinivasan (2014) \\
\hline & MICROWAVE HEATING & & & \\
\hline Red non-tannin sorghum flour & Microwave oven/milling (4 min) & $\uparrow 6.9$ & $\uparrow 11.0$ & Cardoso et al. (2014) \\
\hline Red non-tannin sorghum flour & Milling/microwave oven (4 min) & No change & $\uparrow 14.9$ & Cardoso et al. (2014) \\
\hline Sorghum/whole grain & Microwave in water (450 W/4 min) & $\downarrow 46.4$ & & Hithamani \& Srinivasan (2014) \\
\hline Red non-tanning sorghum flour & Popped grains/milling & No change & & Cardoso et al. (2014) \\
\hline
\end{tabular}

Abbreviations: proanthocyanidins (PRA), 3-deoxyanthocyanidins (3-DXA), DG (decorticated grain), CO (conventional oven). When the matrix is different from whole grain, this is indicated. 
Brewer et al. (2014) evaluated extractable total phenolic compounds in wheat bran with three different particle sizes (coarse: 91\% > $900 \mu \mathrm{m}$; medium: 3\% > $500 \mu \mathrm{m}$ and fine: $3 \%>200 \mu \mathrm{m})$. They noted that a reduction in particle size, and thus an increase in the surface area of the grains, significantly increased the concentration of total phenolic compounds (both bound and soluble), the antioxidant capacity, measured as oxygen radical absorption capacity (ORAC), as well as the extraction of anthocyanins and carotenoids.

The decortication of sorghum involves the removal of the pericarp, usually by abrasion; this process causes a decrease in the content of total phenols in the flour, since the largest proportion of phenols is in the pericarp and aleurone layer. This was reported by Luthria \& Liu (2013), who mentioned that in sorghum, most phenols are found in the outmost layers of the pericarp ( 3 cycles at $1400 \mathrm{rpm}$ ), which means that sorghum bran could be used as a food additive with high antioxidant potential. However, is important to consider that the physical, rheological and sensory properties of grains can be significantly modified. The soaking of cereal grains and legumes is a common practice before cooking; the sole purpose of this procedure is to soften the pericarp and thus reduce the cooking time (Akillioglu \& Karakaya, 2010).

Afify et al. (2012) evaluated the effects of soaking in three varieties of sorghum on the contents of phenolic compounds, flavonoids, tannins, vitamin $\mathrm{E}, \beta$-carotene and antioxidant capacity; they found that soaking significantly reduced the content of total phenols, flavonoids and antioxidant capacity. Soaking for $20 \mathrm{~h}$ reduced the content of total phenols in sorghum by approximately $40 \%$ and reduced the antioxidant capacity by $21 \%$. The decrease in total phenol content and antioxidant capacity during soaking may be explained by extractable phenols being leached into the soaking water, which is usually discarded. The loss of phenolic compounds due to soaking also has been observed in other grains, such as millet and bean (Akillioglu \& Karakaya, 2010; Jha et al., 2015).

\section{Thermal processes}

\subsection{Wet cooking}

Wet cooking a traditional method commonly used to prepare different sorghum-based foods. This procedure is characterized by boiling the cereal in abundant water for variable time periods (10-25 min).

A study on sorghum grains (different cultivars) reported that wet cooking for $12 \mathrm{~min}$ increased the total phenolic acid content in the soluble fraction $(72.8 \%)$, caused mainly by the increase in solubilization of ferulic and $\rho$-coumaric acids, which represented a positive effect on the accessibility of phenolic acids (N'Dri et al., 2013). This same treatment negatively affected the total 3-deoxyanthocyanidin content and total phenolic content, with average losses of $53 \%$ and $45 \%$, respectively. The loss of phenolic compounds caused by wet cooking has a negative effect on the antioxidant capacity of sorghum. It has been observed that the loss of antioxidant capacity of soluble phenols $(75 \%)$ present in cooked sorghum was higher than non-soluble phenols $(-38 \%)$ when these were compared with raw sorghum (N'Dri et al., 2013).

The above results are consistent with those reported by Hithamani \& Srinivasan (2014), who reported an average loss of $50.9 \%$ and $42.9 \%$ in the total content of soluble phenolic compounds in sorghum after subjecting the cereal to wet cooking under pressure (15 psi, $15 \mathrm{~min}$ ) and open-pan boiling (10 min), respectively. They also observed a loss of tannins (22-55\%) and increased phenolic acids, such as caffeic and ferulic acids (up to $200 \%$ and $27-42 \%$ respectively), while $\rho$-coumaric (41\%) and gallic acid (up to $300 \%$ ) increased after cooking open-pan boiling, and syringic acid increased (23\%) after wet cooking under pressure (Hithamani \& Srinivasan, 2014). On the other hand, the cooking of sorghum by open-pan boiling and pressure cooking did not affect the bioaccessible flavonoid content ( $p$-value $>0.05$ ), and only open-pan boiling negatively affected the bioaccessible polyphenol content (12\%) (Hithamani \& Srinivasan, 2014).

The loss of phenolic compounds in sorghum shown for wet cooking was probably attributed to changes or disruption of several structures, such as starch or protein, which could interact with the phenolic compounds and interfere during the extraction (Domínguez-Avila et al., 2017). Another possible explanation could be the sensitivity of phenolic compounds to warming, where the time and temperature of heating are determining factors that affect anthocyanin stability more than phenolic acids and flavonol glycosides (Zori et al., 2014); the flavonoid catechin is more susceptible to thermal degradation than gallic acid and vanillic acid (Volf et al., 2014). Moreover, thermal processing causes the formation of new compounds through decarboxylation and dimerization, just as occurs with ferulic and $\rho$-coumaric acids, which changes its biological potential; for example, the dimerization of ferulic acid and $\rho$-coumaric acid increased their antioxidant activity (Arrieta-Baez et al., 2012).

The loss of phenolic compounds caused by wet cooking may be reduced if cooking is done with minimum amounts of water or if the water evaporates completely after cooking. This was observed in a previous study in which sorghum was heated using steam $\left(200-220^{\circ} \mathrm{C}\right)$ for $20 \mathrm{~min}$; under these conditions, it was possible to reduce the loss of phenolic compounds compared with traditional boiling $\left(100{ }^{\circ} \mathrm{C}\right)$ (Wu et al. 2013). A study conducted by Cardoso et al. (2014) show losses comparable to those obtained by steam cooking. They explained this behavior by arguing that sorghum was dried after having been boiled; with this method, it only lost approximately $8 \%$ of its antioxidant capacity. Wet cooking may be applied to sorghum with a high content of phenolic acids and low flavonoid content, such as red and white sorghums; this increases the solubilization of phenolic acids, which could positively affect its bioaccessibility (Hithamani \& Srinivasan, 2014).

\subsection{Dry cooking}

Dry cooking is usually done in conventional ovens at temperatures above $120^{\circ} \mathrm{C}$. Cardoso et al. (2015) treated different varieties of sorghum (red, yellow and brown pericarp) with conventional oven cooking $\left(121^{\circ} \mathrm{C}, 25 \mathrm{~min}\right)$ and observed that the loss of total phenols was lower than that obtained with 
wet cooking, with retention values between $91.7 \%$ and $105.7 \%$. The same study observed an increase in the antioxidant capacity of the three varieties sorghum evaluated (red, yellow and brown pericarp) due to heat treatment (11-16\%) compared to raw sorghum (Cardoso et al., 2015). Moreover, the cooking of sorghum in a conventional oven is an adequate treatment for the retention or increase in proanthocyanidins with a low degree of polymerization (mono to trimers), 3-deoxyanthocyanidins (luteolinidin, apigeninidin, 5-methoxy-luteolinidin, and 7-methoxy-apigeninidin) but not for the retention of flavones (luteolin and apigenin) or flavanones (naringenin and eriodictyol) (Cardoso et al., 2015). The same research group reported an increase in total phenols (2\%) and antioxidant capacity (8\%, as scavenger radical DPPH activity) in heat-treated red sorghum compared to raw sorghum (Cardoso et al., 2014). The preservation or loss of phenolic compounds during baking differs according to the variety (pericarp color) and group of phenolic compounds.

Roasting is another dry cooking method that involves higher temperatures $\left(150^{\circ} \mathrm{C}\right)$ than baking (Hithamani \& Srinivasan, 2014; Wu et al., 2013). Hithamani \& Srinivasan (2014) reported an average increase in the content of soluble total phenols and tannins in sorghum after roasting at $150{ }^{\circ} \mathrm{C}$ for $5 \mathrm{~min}(49 \%$ and $>100 \%$, respectively), compared to raw sorghum; moreover, the roasting process significantly increased the total phenolic acid content (identified and quantified by HPLC) of sorghum (>200\%); this increase corresponded to the sum of the increases in protocatechuic, ferulic, $\rho$-coumaric, caffeic and sinapic acids (Hithamani \& Srinivasan, 2014). Similar behavior was observed in wheat; however, the increase in total phenolic acids after roasting was lower (52.8\%) than that obtained in sorghum (Hithamani \& Srinivasan, 2014). In contrast, Wu et al. (2013) reported losses of total phenolic content, total flavonoid content, procyanidin content and antioxidant capacity of $42 \%, 21 \%, 48 \%$ and $37 \%$, respectively, when sorghum was subjected to $150{ }^{\circ} \mathrm{C}$ for $1 \mathrm{~h}$; however, the roasted red sorghum grain increased the ferulic acid content in free and bound forms compared to raw grain sorghum, which improved its bioaccessibility (Wu et al., 2013). Based on the results above, it is clear that the time of roasting negatively affected the retention of total phenolic content, total flavonoid content, procyanidin content and antioxidant capacity, and $5 \mathrm{~min}$ at $150^{\circ} \mathrm{C}$ was sufficient for improving the accessible phenolic compounds.

\subsection{Microwave heating}

There are reports that microwave heating damages the arabinoxylans present in cereal grains. In corn, microwave heating $\left(180^{\circ} \mathrm{C}\right.$ for $10 \mathrm{~min}$ or $200^{\circ} \mathrm{C}$ for $2 \mathrm{~min}$ ) can cause the release of approximately $50 \%$ of the content of arabinoxylans as feruloylated arabinoxylan-oligosaccharides with a wide variety of molecular weights and containing up to $8 \mathrm{~g}$ of esterified ferulate/100 g of arabinoxylo-oligosaccharides (Rose \& Inglett, $2010 \mathrm{a})$. Wet heating by microwave $\left(200\right.$ and $210^{\circ} \mathrm{C}$ ) released $70 \%$ of insoluble arabinoxylans and esterified ferulates from wheat bran (30\% of the initial ferulic acid) (Rose \& Inglett, 2010b).

Hithamani \& Srinivasan (2014) reported that boiling sorghum in a microwave for 4 min reduced the contents of soluble total phenols, total flavonoids and tannins by $46.4 \%$, $51.7 \%$, and $29.0 \%$, respectively, which negatively affected its bioaccessibility. The above, possibly due at heating by microwave at $150^{\circ} \mathrm{C}$, compromised the stability of cinnamic acids (caffeic, $\rho$-coumaric, ferulic and sinapic acids), benzoic acids, benzoic aldehydes, flavan-3-ols, among others, through the degradation of hydroxyl-type substituents (Liazid et al., 2007).

The popping process consists of exposing the sorghum grain to high temperature for a short time under dry conditions, generally performed in a microwave, which causes the explosion of the grain due to the super-heated vapor produced inside the grain and the expansion of the starchy endosperm (Mishra et al., 2015). A popping process $\left(250^{\circ} \mathrm{C}\right.$ for $1 \mathrm{~min}, 14-18 \%$ moisture) applied to red and white sorghum reduced the phenolic compound content (free and bound phenols), and antioxidant capacity (ABTS) of sorghum compared to raw sorghum; this reduction could be due the loss of the pericarp or other grain structures during explosion.

On the other hand, the popping process also caused an increase in protein digestibility and iron accessibility (\%) in sorghum compared with raw sorghum. The hard and white sorghum hybrids positively affected the ability of popping, apparent volume and popping performance (\%) compared with popped red sorghum (Llopart \& Drago, 2016). Likewise, the amylose content and pericarp thickness positively influenced the popping yield and volume expansion ratio (Llopart \& Drago, 2016).

In general, the temperature, the absence of water and the heating time are determining factors in the increase or loss of phenolic compounds and antioxidant capacity in sorghum subjected to dry cooking. It has been reported that during dry cooking phenolic compounds remain in the food matrix resulting in lower losses of them (Afify et al., 2012), however, for longer heating periods molecular instability and dimerization take place increasing the losses of bioactive compounds (Arrieta-Baez et al., 2012; Cardoso et al., 2014, 2015). However, the mechanisms involved in these losses have not been clarified yet.

\subsection{Extrusion}

Extrusion consists of thermal and mechanical treatments under conditions of low humidity, shearing, high pressure and temperature for a short time, which result in structural alterations and changes in functional properties (Singh et al., 2007; Wang et al., 2014). Cardoso et al. (2015) observed the depolymerization of proanthocyanidins after the extrusion of brown pericarp sorghum; furthermore, there was an increase in proanthocyanidins with a low degree of polymerization, mainly monomers and dimers (>200\%), compared to raw sorghum. Moreover, the same study reported losses total of flavones (luteolin and apigenin) and losses greater than $80 \%$ and $70 \%$ of flavanones (naringenin and eriodictyol) and 3-deoxyanthocyanidins, respectively, compared with raw sorghum of brown, red and yellow pericarp (Cardoso et al., 2015). However, the retention of total phenolic content and antioxidant capacity was held at values approximately of $84 \%$ and $91 \%$, respectively.

White sorghum bran extruded at $180{ }^{\circ} \mathrm{C}(20 \%$ moisture $)$ showed a significant increase in the solubilization of total phenolic 
content, caffeic, $\rho$-coumaric, ferulic and sinapic acids ( $52 \%, 33 \%$, $71 \%,>100 \%$ and $91 \%$ ) compared to non-extruded sorghum bran; furthermore, an increase in the antiradical capacity (DPPH, ABTS) and an increase in the potential anti-inflammatory capacity was observed through an evaluation of inhibition of nitric oxide production by RAW cells induced with LPS (Salazar Lopez et al., 2016).

The increase in total phenol content and biological potential in sorghum after extrusion could be attributed to the increase in low-molecular-weight proanthocyanidins, formation of other compounds during the extrusion process or increase in extractability due the breakdown of structures from the cell well (Cardoso et al., 2015; Salazar Lopez et al., 2016).

Dlamini et al. (2007) subjected whole or decorticated grains of different varieties of sorghum to extrusion $\left(150-160{ }^{\circ} \mathrm{C}\right.$, 30-90 s) and observed losses of total phenolic compounds and antioxidant capacity in whole sorghum of up to $61.6 \pm 17.6 \%$ and $83 \pm 4.3 \%$, respectively. However, when evaluating decorticated sorghum, different values were observed according to whether the varieties had tannins. Sorghum varieties with tannins had average losses of total phenolic compounds and antioxidant capacity (ABTS) of $43 \pm 27 \%$ and $69.7 \pm 13 \%$, respectively; the opposite results were found in non-tannin varieties, which had minimal losses, and there was even a variety that showed an increase of $70 \%$ in total phenolic content and of $157 \%$ in antioxidant activity. On the other hand, extruded red sorghum showed a reduction of total extractable phenol content $(<41 \%)$, and antioxidant capacity $(<24.8 \%)$ compared to raw sorghum; however, an increase in protein digestibility (31\%) and available lysine (25.4\%) was shown (Llopart et al., 2014).

The effect of extrusion on the content of nutritive and non-nutritive components, such as phenolic compounds, depends on the processing conditions and the food matrix (Singh et al., 2007). Extrusion is a promising process for the manufacture of functional cereal-based foods, as it preserves or increases the content of phenolic compounds. In sorghum, due to the structural arrangement of phenolic acids, it is recommended to use high temperatures during the extrusion process to break the ether bonds that link ferulic acid with lignin; also, the extrusion process may break the glycosidic bonds that link xyloses, increasing the possibility of forming feruloylated oligomers, which have been reported as having antioxidant activity (Ayala-Soto et al., 2014, 2015).

In cereals such as sorghum, quinoa or amaranth, it is required to optimize the extrusion conditions to obtain extruded products with expansion properties and performance similar to those of wheat (Robin et al., 2015). Is important to know the chemical composition of sorghum because of the high content of branched carbohydrates and low fiber content that lead to positive impacts on the elasticity and size of the extruded product (Vargas-Solórzano et al., 2014). The sorghum genotype plays an important role during the elaboration of products on base sorghum with biological potential. Red and light-brown sorghum, which have a high tannin and fiber content, are appropriate for whole-grain sorghum breakfast production due to their low solubility in warm water; in contrast, sorghum genotypes with high water diffusion at ambient temperature are suitable for preparing instant beverages (Vargas-Solórzano et al., 2014).

Whole-grain sorghum-based breakfast cereals have higher sensory acceptance (70.6\%) and total phenolic compounds (98.2\%), antioxidant activity (87.9\%) and 3-deoxyanthocyanidin content $(100 \%)$ than breakfast cereals based on whole-grain wheat, both of which are prepared by extrusion (Anunciação et al., 2017). Extruded white non-tannin sorghum showed similar values of in vitro protein digestibility, rapidly digestible starch, slowly digestible starch, resistant starch, overall acceptability and texture than an oat-extruded reference; therefore, sorghum has been recommended to be used in the production of breakfast cereals (Mkandawire et al., 2015). Sorghum has been used to obtain extruded products containing low-digestion starch, achieving in this way healthy levels of circulating glucose (Licata et al., 2015). Extrusion of sorghum also has been proposed to produce functional foods, such as gluten-free snacks, which are nutritious and healthy for celiac disease patients (Lohani \& Muthukumarappan, 2016).

\section{Bioprocessing}

\subsection{Fermentation}

Fermentation is a biological process that increases the digestibility of sorghum proteins; it is widely used by African people for preparing a traditional porridge-like food (Dlamini et al., 2007; Zaroug et al., 2014). However, other effects have also been observed on bioactive compounds present in sorghum; for instance, fermentation with Lactobacillus has been shown to significantly affect the content of polyphenols and antimicrobial activity of red sorghum, mediated by the presence of glucosidase, phenolic acid reductase, and phenolic acid decarboxylase, during lactic fermentation, which can metabolize phenolic acids, phenolic acid esters, and flavonoid glucosides (Svensson et al., 2010).

The addition of whole-grain white sorghum flour (WSF, $40 \%$ ) or red sorghum flour (RSF, $40 \%$ ) to wheat flour (WF) used for flat bread elaboration (fermented for $75 \mathrm{~min}$ and baked in a fan-forced oven at $300^{\circ} \mathrm{C}$ ) increased the total phenolic content and antioxidant capacity of RSF flat bread and WSF flat bread compared to a flat bread control (100\% WF); likewise, the fast-digestion starch level was lower in WSF and RSF flat breads than the control without affecting the sensory preference of the flat breads (Yousif et al., 2012). On the other hand, Zaroug et al. (2014) evaluated the contents of phenolic compounds in tannin and non-tannin sorghum during fermentation and baking. They reported that fermented dough prepared from non-tannin sorghum showed an increase in the total phenol and flavonoid content and antioxidant capacity compared to raw sorghum. The content of total phenols after 8 and $24 \mathrm{~h}$ (10.6 \pm 0.5 and $18.4 \pm 0.6 \mathrm{mg} \mathrm{GAE} / \mathrm{g}$, respectively), compared with the values at $0 \mathrm{~h}(7.2 \pm 1.5 \mathrm{mg} \mathrm{GAE} / \mathrm{g})$, showed that the fermentation time was a determining factor in the release of phenolic compounds. In the same study, fermented dough was cooked on a hot plate for 1-2 seconds, and no adverse effects on total phenolic content were observed (Zaroug et al., 2014). These results are the opposite of those obtained by Dlamini et al. (2007), who studied a fermented dough made from different 
varieties of sorghum, and reported a decrease in total phenolic content, tannins and antioxidant capacity. Apparently, the sorghum variety, the time of fermentation and possibly even the inoculum employed had a direct influence on the content of phenolic compounds in fermented products, so that optimized fermentation could be an alternative in the modification of sorghum matrix and release of phenolic compounds.

\subsection{Enzymes}

Enzyme treatments have been widely used in the processing of several cereals (Uraji et al., 2013). There are few studies regarding use of enzymes in sorghum flour. Feruloyl esterase is the enzyme responsible for the release of phenolic acids bound to arabinoxylans present in grain cell walls. Feruloyl esterase catalyzes the hydrolysis of the ester linkage between sugars (arabinose) and hydroxycinnamic acids. This enzyme performs a function similar to alkaline hydrolysis in relation to the deesterification of feruloylated arabinoxylans in plant cell walls (Huang et al., 2013; Rosa et al., 2013).

The disintegration of the aleurone layer by enzymatic treatment with xylanase or xylanase and feruloyl esterase solubilized $43 \%$ and $82 \%$ of arabinoxylans, respectively. Treatment with only xylanase produced $17 \%$ of bioavailable ferulic acid (free and conjugated forms), while treatment with both enzymes produced $87 \%$ of bioavailable ferulic acid, significantly changing the metabolism of this phenolic acid. The ferulic acid contained in wheat aleurone treated with both enzymes, xylanase and feruloyl esterase, is metabolized and absorbed to the portal vein from the stomach and upper intestine, while the bioavailability of ferulic acid bound to the arabinoxylans is dependent on its release by intestinal microbiota; therefore, its metabolization is performed in the colon, so that the urinary excretion of free ferulic acid and bound ferulic acid is different (Pekkinen et al., 2014).

Rosa et al. (2013) reported an increase of $86 \%$ in the bioavailability of ferulic acid due to the processing of wheat aleurone with xylanase and ferulic esterase. Huang et al. (2013) increased the release of free ferulic acid $(310 \mu \mathrm{M})$ from lignocellulose (de-starched wheat bran) using a thermostable esterase produced from thermophilic actinomycetes (Thermobifida fusca) to hydrolyze ester linkages. The increase in released ferulic acid increased the antioxidant activity, as evaluated with the DPPH and ABTS methods.

Shin et al. (2006) evaluated the release of ferulic acid from corn residues by chemical hydrolysis and the use of a mixture of enzymes from Neosartorya spinosa NRRL185 $\left(40^{\circ} \mathrm{C}, 24 \mathrm{~h}\right)$; they reported no differences between the concentrations obtained by chemical hydrolysis and enzymatic hydrolysis $(0.3$ and $0.3 \mathrm{mg} / 10 \mathrm{mg}$ of bran, respectively).

A study conducted by Agger et al. (2010) evaluated different enzyme mixtures regarding the release of xylose contained in the glucuronoarabinoxylan (GAX) of corn; the largest amount of ferulic acid released was obtained when they used an enzyme mixture that included endoxylanase, $\beta$-xylosidase and two $\beta$-L-arabinofuranosidase, in addition to feruloyl esterase (Meripilus giganteus and Humicola insolens). A study of sweet sorghum bagasse showed that the use of combined cellulase and endo-xylanase was able to modify the cell wall of sorghum toward a less complex structure (Pengilly et al., 2015), which could improve the extractability of phenolic compounds. It is possible to consider that, given the similarities between the arabinoxylans in corn and sorghum, in terms of its complexity, the enzymatic processing mentioned above could be a promising method for releasing phenolic compounds from sorghum. Studies of the effects of enzymatic treatment on bran and whole-grain sorghum are currently being conducted by our research group.

\subsection{Sprouting}

There are numerous studies of the effects of sprouting or germination of cereals on the nutritive quality of cereals (Hithamani \& Srinivasan, 2014; Afify et al., 2012). Reactions in germinating grain lead to structural modification and the synthesis of new compounds, some of which have high bioactivity and can increase the nutritional value of the grains (Pradeep \& Sreerama, 2015). The wet conditions in which germination occurs allow the grain to absorb a certain amount of water, giving rise to biochemical and physiological changes, such as the activation of hydrolytic enzymes that are inactive in raw seeds, such as amylases, proteases, lipases, fiber-degrading enzymes, and phytases, which contribute to the breakdown of macromolecules (proteins, carbohydrates and lipids), increasing accessibility and digestibility (Yan et al., 2010). The decomposition of high-molecular-weight polymers during germination leads to the generation of biofunctional substances. Hithamani \& Srinivasan (2014) observed an increase in the content of soluble total phenols, tannins and phenolic acids after sprouting; however, when phenolic acids were analyzed individually, there was an increase in the content of protocatechuic $(>100 \%)$, ferulic $(20 \%)$ and salicylic (10\%) acids after sprouting and a decrease in the content of others, such as gallic, syringic and $\rho$-coumaric acids. This decrease was $15 \%$ compared to unprocessed sorghum. This behavior was not observed in sprouted wheat, in which total phenolic acids increased by $1 \%$ (Hithamani \& Srinivasan, 2014). The effect of germination on phenolic compounds and antioxidant activities in 50 sorghum varieties showed that, on average, germination did not affect the content of total phenolic compounds but decreased the content of proanthocyanidins, 3-deoxyanthocyanidins, and flavan-4-ols (Dicko et al., 2005). In other cereals and pseudocereals (methanolic extracts), such as amaranth, quinoa, buckwheat and wheat, the total phenolic content in the free form was increased twofold after the sprouting process and was reduced after baking (Alvarez-Jubete et al., 2010). Similar to the previous technologies, during germination, the time, the temperature and the variety are determining factors in the release of phenolic compounds. The increase in phenolic compounds in the free from, the reduction of anti-nutritional compounds and the low processing cost are advantages in the elaboration of functional foods from sorghum.

\section{Chemical technologies}

\subsection{Nixtamalization}

The nixtamalization process consists of alkaline cooking of maize with lime and is used traditionally in Mexico as the primary process to produce tortillas, chips and tamales 
(Moreno-Rivas et al., 2014). Basically, the objective of nixtamalization is to improve some nutritional and sensorial characteristics of the products obtained. However, it is not only the nutritional and sensory properties that have been improved with the nixtamalization process; in the last several years, the process of nixtamalization has also been studied as a technology to improve its content of phenolic compounds. In a study, tortillas produced with traditionally nixtamalizated corn retained significantly less total phenolic and total ferulic acid (50.5-75.7 and 19.6-55.8\%, respectively) compared with tortillas prepared with extruded corn flour (76.2-93.9\% and 58-96.7\%, respectively), which negatively affected the antioxidant capacity (Mora-Rochin et al., 2010). However, traditionally nixtamalizated corn increased the accessibility of ferulic acid compared with raw corn and tortillas produced with extruded corn. In addition to corn, sorghum has been a good candidate to be subjected to the process of nixtamalization, particularly because they share some chemical and anatomical characteristics. The nixtamalization of sorghum causes loss of tannin, which is due to the removal of pericarp during alkaline cooking, where the major proportion of phenolic compounds is localized (Ocheme et al., 2010). This process could be adequate for the treatment of white sorghum, which has a minimum amount of tannins, high content of hydroxycinnamic acid in the bound form, and is not adequate for black and brown pericarp, which have a high proportion of flavonoids in the free form (Wu et al., 2017).

\section{Trends and innovations}

\subsection{Pulsed electric fields}

The use of pulsed electric fields (PEF) of high intensity for a short time causes increases in the permeability of the cytoplasmic membrane and the release of intracellular compounds (Lohani \& Muthukumarappan, 2016). Fermented sorghum flour processed with PEF (45\% w/v, $2 \mathrm{kV} / \mathrm{cm}$ electric field intensity and $875 \mu \mathrm{s}$ treatment time) showed increases in total phenolic content and antioxidant activity of $24.8 \%$ and $33.9 \%$, respectively compared with the control; likewise, fermentation and electroporation caused cell disruption and the release of benzoic and cinnamic acids (Lohani \& Muthukumarappan, 2016). The processing of sorghum flour by PEF permitted the release of bound phenolic and increased the total phenolic content and antioxidant capacity with minimal damage to other nutrients (Lohani \& Muthukumarappan, 2016); however, it had the disadvantage of requiring a greater amount of water compared with other technologies, such as extrusion or fermentation.

\subsection{Irradiation}

Irradiation is a physical treatment that involves the exposure of food products to ionizing or non-ionizing radiation for the purpose of food preservation. However, in the last several years, great interest has been emerging regarding the use of irradiation to improve the phenolic content and antioxidant capacity of food, especially focused on fruits and vegetables, with studies in cereals and particularly sorghum being scarce. A study conducted by Mukisa et al. (2012) investigated the effects of gamma irradiation and re-irradiation on microbial decontamination, viscosity, amylase activity and starch granule structure of sorghum; it revealed that gamma irradiation could be used to decontaminate flours and to produce weaning porridge from sorghum. Another study, by Duodu et al. (1999), reported that cooking did not decrease phytic acid in sorghum porridge, but the combination of cooking and irradiation ( $1 \mathrm{kGy}$ ) resulted in a significant decrease (40\%). Fombang et al. (2005) studied the effects of irradiation of dry and wet sorghum flours on the digestibility and solubility of their proteins. When the flours were cooked into porridge, they found that irradiation ( $10 \mathrm{kGy})$ applied to dry sorghum flour alleviated the adverse effect of cooking on sorghum protein digestibility. The same study examined the effects of irradiation on polyphenol content and antioxidant activity in sorghum flour and porridges; it found that polyphenols were reduced more by irradiation combined with cooking than by irradiation or cooking alone.

In general, the decrease in antioxidants is attributed to the formation of radiation-induced degradation products or the formation of free radicals (Manupriya et al., 2016; Hussain et al., 2014).

\section{Other methods of processing}

Another technology applied for the release of phenolic acids from cereals is steam explosion-assisted extraction, which has shown significant improvements in soluble free and conjugated phenolic acids as well as the antioxidant properties of wheat bran (Liu et al., 2016). In addition to the techniques to improve the content of phenolic compounds in sorghum described above, there are other methods of processing, such as the application of ohmic heating and high hydrostatic pressures, among others. However, although these are promising methods of food preservation, there are still few studies of their effect on cereals and, as far as we know, no studies on their effect on sorghum, although they have shown some beneficial effects in other grains, such as wheat.

\section{Other considerations}

Due to the high phenolic compound content and low protein digestibility in sorghum, it is recommended for the production of functional foods in combinations with other cereals. Promising examples could be the addition of sorghum to cowpea (Apea-Bah et al., 2016; Vilakati et al., 2016), roasted coffee (Chávez et al., 2017), wheat flour (Yousif et al., 2012), and barley (Rudra et al. 2015), where the results have been consistent in terms of improving the nutritive value, antioxidant properties and phenolic compounds. The nutritional value and sensorial characteristics of pasta obtained from a combination of sorghum and wheat semolina (50:50,60:40, and 70:30) and subjected to an extrusion process have also been studied (Benhur et al., 2015).

Other studies have demonstrated the possibility of produce sorghum cultivars with a high content of phenols for the elaboration of products with biological potential through the agronomic manipulation of sorghum cultivation. Six sorghum genotypes with deficit irrigation during their cultivation showed significantly increased whole-grain phenolic contents, such as 3-deoxyanthocyanidins, flavones, dihydroflavonol, flavanone, and hydroxycinnamic acids (caffeic and ferulic acids). Likewise, there was increased antioxidant activity evaluated with DPPH and ABTS 
assays compared to the full irrigation treatment; that increase was affected by the genotype (Wu et al., 2017).

\section{Conclusions}

There are numerous technological processes that can be used in sorghum and their products to improve their phenolic content and consequently, their bioaccessibility. These behaviors may be evaluated depending on the variety, physical and chemical constitution of the grains. The varieties with a greater proportion of phenolic compounds in the free form (black and brown) must be processed with lower-impact technologies, for example, fermentation, pulsed electric fields and soaking (water not discarded). In contrast, sorghum varieties with a large proportion of phenolic compounds in the bound form, such as white sorghum, could be processed with technologies that intensely modify its structure, such as alkaline cooking, extrusion, and sprouting.

According to the existing literature, it is possible to conclude that biological and thermomechanical processes with low moisture might be successfully used to obtain sorghum-based products with beneficial effects on human health. Sorghum can easily compete with the most widely consumed cereals, such as wheat and corn, in terms of its nutritional and functional characteristics. Its inclusion as part of a healthy diet can be justified, but further chemical and biochemical studies are needed to better understand the nature of its bioactive constituents and how they behave under the effects of the different processes that could be applied to sorghum and its products. Studies revealing an increase in the bioaccessibility of phenolic compounds attributed to thermal processes on sorghum are in progress.

\section{References}

Acosta-Estrada, B. A., Gutiérrez-Uribe, J., \& Serna-Saldívar, S. O. (2014). Bound phenolics in foods, a review. Food Chemistry, 152, 46-55. http://dx.doi.org/10.1016/j.foodchem.2013.11.093. PMid:24444905.

Afify, A. E. M. M., El-Beltagi, H. S., El-Salam, S. M. A., \& Omran, A. A. (2012). Biochemical changes in phenols, flavonoids, tannins, vitamin E, $\beta$-carotene and antioxidant activity during soaking of three white sorghum varieties. Asian Pacific Journal of Tropical Biomedicine, 2(3), 203-209. http://dx.doi.org/10.1016/S2221-1691(12)60042-2. PMid:23569898.

Agger, J., Viksø-Nielsen, A., \& Meyer, A. S. (2010). Enzymatic xylose release from pretreated corn bran arabinoxylan: differential effects of deacetylation and deferuloylation on insoluble and soluble substrate fractions. Journal of Agricultural and Food Chemistry, 58(10), 61416148. http://dx.doi.org/10.1021/jf100633f. PMid:20411987.

Akillioglu, H. G., \& Karakaya, S. (2010). Changes in total phenols, total flavonoids, and antioxidant activities of common beans and pinto beans after soaking, cooking, and in vitro digestion process. Food Science and Biotechnology, 19(3), 633-639. http://dx.doi.org/10.1007/ s10068-010-0089-8.

Alvarez-Jubete, L., Wijngaard, H., Arendt, E. K., \& Gallagher, E. (2010). Polyphenol composition and in vitro antioxidant activity of amaranth, quinoa buckwheat and wheat as affected by sprouting and baking. Food Chemistry, 119(2), 770-778. http://dx.doi.org/10.1016/j. foodchem.2009.07.032.

Anunciação, P. C., Cardoso, L. de M., Gomes, J. V. P., Della Lucia, C. M., Carvalho, C. W. P., Galdeano, M. C., Queiroz, V. A. V., Alfenas, R. C.
G., Martino, H. S. D., \& Pinheiro-Sant'Ana, H. M. (2017). Comparing sorghum and wheat whole grain breakfast cereals : Sensorial acceptance and bioactive compound content. Food Chemistry, 221, 984-989. http://dx.doi.org/10.1016/j.foodchem.2016.11.065. PMid:27979303.

Apea-Bah, F. B., Minnaar, A., Bester, M. J., \& Duodu, K. G. (2016). Sorghum - cowpea composite porridge as a functional food, Part II : Antioxidant properties as affected by simulated in vitro gastrointestinal digestion. Food Chemistry, 197(Pt A), 307-315. http://dx.doi.org/10.1016/j.foodchem.2015.10.121. PMid:26616954.

Arrieta-Baez, D., Dorantes-Álvarez, L., Martinez-Torres, R., ZepedaVallejo, G., Jaramillo-Flores, M. E., Ortiz-Moreno, A., \& AparicioOzores, G. (2012). Effect of thermal sterilization on ferulic, coumaric and cinnamic acids: dimerization and antioxidant activity. Journal of the Science of Food and Agriculture, 92(13), 2715-2720. http:// dx.doi.org/10.1002/jsfa.5695. PMid:22522234.

Awika, J. M., \& Rooney, L. W. (2004). Sorghum phytochemicals and their potential impact on human health. Phytochemistry, 65(9), 1199-1221. http://dx.doi.org/10.1016/j.phytochem.2004.04.001. PMid:15184005.

Awika, J. M., Rooney, L. W., Wu, X., Prior, R. L., \& Cisneros-Zevallos, L. (2003). Screening methods to measure antioxidant activity of sorghum (sorghum bicolor) and sorghum products. Journal of Agricultural and Food Chemistry, 51(23), 6657-6662. http://dx.doi. org/10.1021/jf034790i. PMid:14582956.

Awika, J. M., Yang, L., Browning, J. D., \& Faraj, A. (2009). Comparative antioxidant, antiproliferative and phase II enzyme inducing potential of sorghum (Sorghum bicolor) varieties. Lebensmittel-Wissenschaft + Technologie, 42(6), 1041-1046. http://dx.doi.org/10.1016/j. lwt.2009.02.003.

Ayala-Soto, F. E., Serna-Saldívar, S. O., García-Lara, S., \& PérezCarrillo, E. (2014). Hydroxycinnamic acids, sugar composition and antioxidant capacity of arabinoxylans extracted from different maize fiber sources. Food Hydrocolloids, 35, 471-475. http://dx.doi. org/10.1016/j.foodhyd.2013.07.004.

Ayala-Soto, F. E., Serna-Saldivar, S. O., Welti-Chanes, J., \& GutierrezUribe, J. A. (2015). Phenolic compounds, antioxidant capacity and gelling properties of glucoarabinoxylans from three types of sorghum brans. Journal of Cereal Science, 65, 277-284. http://dx.doi. org/10.1016/j.jcs.2015.08.004.

Benhur, D. R., Bhargavi, G., Kalpana, K., Vishala, A. D., Ganapathy, K. N., \& Patil, J. V. (2015). Development and standardization of sorghum pasta using extrusion technology. Journal of Food Science and Technology, 52(10), 6828-6833. http://dx.doi.org/10.1007/ s13197-015-1801-8. PMid:26396437.

Brewer, L. R., Kubola, J., Siriamornpun, S., Herald, T. J., \& Shi, Y. C. (2014). Wheat bran particle size influence on phytochemical extractability and antioxidant properties. Food Chemistry, 152, 483-490. http:// dx.doi.org/10.1016/j.foodchem.2013.11.128. PMid:24444965.

Burdette, A., Garner, P. L., Mayer, E. P., Hargrove, J. L., Hartle, D. K., \& Greenspan, P. (2010). Anti-Inflammatory activity of select sorghum (Sorghum bicolor) brans. Journal of Medicinal Food, 13(4), 879-887. http://dx.doi.org/10.1089/jmf.2009.0147. PMid:20673059.

Cardoso, L. M., Montini, T. A., Pinheiro, S. S., Pinheiro-Sant'Ana, H. M., Martino, H. S. D., \& Moreira, A. V. B., A. V. (2014). Effects of processing with dry heat and wet heat on the antioxidant profile of sorghum. Food Chemistry, 152, 210-217. http://dx.doi.org/10.1016/j. foodchem.2013.11.106. PMid:24444928.

Cardoso, L. M., Pinheiro, S. S., Carvalho, C. W. P., Queiroz, V. A. V., Menezes, C. B., Moreira, A. V. B., Barros, F. A. R., Awika, J. M., Martino, H. S. D., \& Pinheiro-Sant'Ana, H. M. (2015). Phenolic compounds profile in sorghum processed by extrusion cooking 
and dry heat in a conventional oven. Journal of Cereal Science, 65, 220-226. http://dx.doi.org/10.1016/j.jcs.2015.06.015.

Cardoso, L. M., Pinheiro, S. S., Martino, H. S., \& Pinheiro-Sant'Ana, H. M., (2017). Sorghum (Sorghum bicolor L.): Nutrients, bioactive compounds, and potential impact on human health. Critical Reviews in Food Science and Nutrition, 57(2), 372-390. http://dx.doi.org/10. 1080/10408398.2014.887057. PMid:25875451.

Chávez, D. W. H., Ascheri, J. L. R., Carvalho, C. W. P., Godoy, R. L. O., \& Pacheco, S. (2017). Sorghum and roasted coffee blends as a novel extruded product: Bioactive compounds and antioxidant capacity. Journal of Functional Foods, 29, 93-103. http://dx.doi.org/10.1016/j. jff.2016.12.012.

Chiremba, C., Taylor, J. R. N., Rooney, L. W., \& Beta, T. (2012). Phenolic acid content of sorghum and maize cultivars varying in hardness. Food Chemistry, 134(1), 81-88. http://dx.doi.org/10.1016/j. foodchem.2012.02.067.

Choi, Y., Jeong, H. S., \& Lee, J. (2007). Antioxidant activity of methanolic extracts from some grains consumed in Korea. Food Chemistry, 103(1), 130-138. http://dx.doi.org/10.1016/j.foodchem.2006.08.004.

Dicko, M. H., Gruppen, H., Traore, A. S., van Berkel, W. J., \& Voragen, A. G. (2005). Evaluation of the Effect of Germination on Phenolic Compounds and Antioxidant Activities in Sorghum Varieties. Journal of Agricultural and Food Chemistry, 53(7), 2581-2588. http://dx.doi. org/10.1021/jf0501847. PMid:15796598.

Dlamini, N. R., Taylor, J. R. N., \& Rooney, L. W. (2007). The effect of sorghum type and processing on the antioxidant properties of African sorghum-based foods. Food Chemistry, 105(4), 1412-1419. http://dx.doi.org/10.1016/j.foodchem.2007.05.017.

Domínguez-Avila, J. A., Wall-Medrano, A., Velderrain-Rodríguez, G. R., Chen, C. O., Salazar-López, N. J., Robles-Sánchez, M., \& GonzálezAguilar, G. A. (2017). Gastrointestinal interactions, absorption, splanchnic metabolism and pharmacokinetics of orally ingested phenolic compounds. Food \& Function, 8(1), 15-38. http://dx.doi. org/10.1039/C6FO01475E. PMid:28074953.

Duodu, K. G., Minnaar, A., \& Taylor, J. R. N. (1999). Effect of cooking and irradiation on the labile vitamins and antinutrient content of a traditional african sorghum porridge and spinach relish. Food Chemistry, 66(1), 21-27. http://dx.doi.org/10.1016/S0308-8146(98)00070-3.

Dvořáková, M., Guido, L. F., Dostálek, P., Skulilová, Z., Moreira, M. M., \& Barros, A. A. (2008). Antioxidant properties of free, soluble ester and insoluble-bound phenolic compounds in different barley varieties and corresponding malts. The Institute of Brewing and Distilling, 114(1), 27-33. http://dx.doi.org/10.1002/j.2050-0416.2008.tb00302.x.

Dykes, L. Jr, Hoffmann, L. Jr, Portillo-Rodriguez, O., Rooney, W. L., \& Rooney, L. W. (2014). Prediction of total phenols, condensed tannins, and 3-deoxyanthocyanidins in sorghum grain using near-infrared (NIR) spectroscopy. Journal of Cereal Science, 60(1), 138-142. http:// dx.doi.org/10.1016/j.jcs.2014.02.002.

Dykes, L., Rooney, L. W., Waniska, R. D., \& Rooney, W. L. (2005). Phenolic compounds and antioxidant activity of sorghum grains of varying genotypes. Journal of Agricultural and Food Chemistry, 53(17), 6813-6818. http://dx.doi.org/10.1021/jf050419e. PMid:16104804.

Dykes, L., Rooney, W. L., \& Rooney, L. W. (2013). Evaluation of phenolics and antioxidant activity of black sorghum hybrids. Journal of Cereal Science, 58(2), 278-283. http://dx.doi.org/10.1016/j.jcs.2013.06.006.

Fombang, E. N., Taylor, J. R. N., Mbofung, C. M. F., \& Minnaar, A. (2005). Use of $\gamma$-irradiation to alleviate the poor protein digestibility of sorghum porridge. Food Chemistry, 91(4), 695-703. http://dx.doi. org/10.1016/j.foodchem.2004.06.042.
Guo, W., \& Beta, T. (2013). Phenolic acid composition and antioxidant potential of insoluble and soluble dietary fibre extracts derived from select whole-grain cereals. Food Research International, 51(2), 518525. http://dx.doi.org/10.1016/j.foodres.2013.01.008.

Hithamani, G., \& Srinivasan, K. (2014). Bioaccessibility of polyphenols from wheat (Triticum aestivum), sorghum (Sorghum bicolor), green gram (Vigna radiata), and chickpea (Cicer arietinum) as influenced by domestic food processing. Journal of Agricultural and Food Chemistry, 62(46), 11170-11179. http://dx.doi.org/10.1021/ jf503450u. PMid:25340251.

Huang, Y., Chen, C., Chen, W., Ciou, Y., Yang, T., \& Yang, C. (2013). Production and antioxidant properties of the ferulic acid-rich destarched wheat bran hydrolysate by feruloyl esterases from thermophilic actinomycetes. BioResources, 8(4), 4981-4991. http:// dx.doi.org/10.15376/biores.8.4.4981-4991.

Hussain, P. R., Wani, I. A., Suradkar, P. P., \& Dar, M. A. (2014). Gamma irradiation induced modification of bean polysaccharides: Impact on physicochemical, morphological and antioxidant properties. Carbohydrate Polymers, 110, 183-194. http://dx.doi.org/10.1016/j. carbpol.2014.03.028. PMid:24906745.

Jakobek, L. (2015). Interactions of polyphenols with carbohydrates, lipids and proteins. Food Chemistry, 175, 556-567. http://dx.doi. org/10.1016/j.foodchem.2014.12.013. PMid:25577120.

Jha, N., Krishnan, R., \& Meera, M. S. (2015). Effect of different soaking conditions on inhibitory factors and bioaccessibility of iron and zinc in pearl millet. Journal of Cereal Science, 66, 46-52. http://dx.doi. org/10.1016/j.jcs.2015.10.002.

Kang, J., Price, W. E., Ashton, J., Tapsell, L. C., \& Johnson, S. (2016). Identification and characterization of phenolic compounds in hydromethanolic extracts of sorghum wholegrains by LC-ESIMS n. Food Chemistry, 211, 215-226. http://dx.doi.org/10.1016/j. foodchem.2016.05.052. PMid:27283625.

Liazid, A., Palma, M., Brigui, J., \& Barroso, C. G. (2007). Investigation on phenolic compounds stability during microwave-assisted extraction. Journal of Chromatography. A, 1140(1-2), 29-34. http://dx.doi. org/10.1016/j.chroma.2006.11.040. PMid:17141250.

Licata, R., Coorey, R., Zhao, Y., Chu, J., \& Johnson, S. (2015). Maximizing slowly digested starch in an expanded sorghum-maize extruded food using response surface methodology. Stärke, 67(3-4), 285-293. http://dx.doi.org/10.1002/star.201400191.

Lin, P., Wong, J. H., Ng, T. B., Ho, V. S. M., \& Xia, L. (2013). A sorghum xylanase inhibitor-like protein with highly potent antifungal, antitumor and HIV-1 reverse transcriptase inhibitory activities. Food Chemistry, 141(3), 2916-2922. http://dx.doi.org/10.1016/j. foodchem.2013.04.013. PMid:23871041.

Liu, L., Zhao, M., Liu, X., Zhong, K., Tong, L., Zhou, X., \& Zhou, S. (2016). Effect of steam explosion-assisted extraction on phenolic acid profiles and antioxidant properties of wheat bran. Journal of the Science of Food and Agriculture, 96(10), 3484-3491. http://dx.doi. org/10.1002/jsfa.7532. PMid:26572692.

Llopart, E. E., \& Drago, S. R. (2016). Physicochemical properties of sorghum and technological aptitude for popping nutritional changes after popping. Lebensmittel-Wissenschaft + Technologie, 71, 316-322. http://dx.doi.org/10.1016/j.lwt.2016.04.006.

Llopart, E. E., Drago, S. R., De Greef, D. M., Torres, R. L., \& González, R. J. (2014). Effects of extrusion conditions on physical and nutritional properties of extruded whole grain red sorghum (sorghum spp). International Journal of Food Sciences and Nutrition, 65(1), 34-41. http://dx.doi.org/10.3109/09637486.2013.836737. PMid:24059748.

Lohani, U. C., \& Muthukumarappan, K. (2016). Application of the pulsed electric field to release bound phenolics in sorghum flour 
and apple pomace. Innovative Food Science \& Emerging Technologies, 35, 29-35. http://dx.doi.org/10.1016/j.ifset.2016.03.012.

Lopez-Martinez, L. X., Oliart-Ros, R. M., Valerio-Alfaro, G., Lee, C. H., Parkin, K. L., \& Garcia, H. S. (2009). Antioxidant activity, phenolic compounds and anthocyanins content of eighteen strains of Mexican maize. Lebensmittel-Wissenschaft + Technologie, 42(6), 1187-1192. http://dx.doi.org/10.1016/j.lwt.2008.10.010.

Luthria, D. L., \& Liu, K. (2013). Localization of phenolic acids and antioxidant activity in sorghum kernels. Journal of Functional Foods, 5(4), 1751-1760. http://dx.doi.org/10.1016/j.jff.2013.08.001.

Manupriya, B. R., Shenoy, K. B., Patil, S. L., \& Somashekarappa, H. M. (2016). Effect of gamma radiation on total antioxidant capacity, total lipid concentration and shelf life of finger millet flour. Journal of Radiation and Cancer Research, 7(1), 22.

Mishra, G., Joshi, D. C., Mohapatra, D., \& Babu, V. B. (2015). Varietal influence on the microwave popping characteristics of sorghum. Journal of Cellular Biochemistry, 65, 19-24.

Mkandawire, N. L., Weier, S. A., Weller, C. L., Jackson, D. S., \& Rose, D. J. (2015). Composition, in vitro digestibility, and sensory evaluation of extruded whole grain sorghum breakfast cereals. Lebensmittel-Wissenschaft + Technologie, 62(1), 662-667. http:// dx.doi.org/10.1016/j.lwt.2014.12.051.

Morales Ortega, A., Niño Medina, G., Carvajal Millan, E., Gardea Bejar, A., Torres Chavez, P., López Franco, Y., Rascon Chu, A., \& Lizardi Mendoza, J. (2013). Ferulated arabinoxylans from cereals. A review of their physico-chemical characteristics and gelling capability. Revista Fitotecnia Mexicana, 36(4), 439-446.

Mora-Rochin, S., Gutiérrez-Uribe, J. A., Serna-Saldivar, S. O., SánchezPeña, P., Reyes-Moreno, C., \& Milán-Carrillo, J. (2010). Phenolic content and antioxidant activity of tortillas produced from pigmented maize processed by conventional nixtamalization or extrusion cooking. Journal of Cereal Science, 52(3), 502-508. http://dx.doi. org/10.1016/j.jcs.2010.08.010.

Moreno-Rivas, S. C., Medina-Rodríguez, C. L., Torres-Chávez, P. I., Ramírez-Wong, B., \& Platt-Lucero, L. C. (2014). Changes in the solubility of corn proteins through interaction with the arabinoxylans in extruded nixtamalized corn flour treated with xylanase. Plant Foods for Human Nutrition (Dordrecht, Netherlands), 69(2), 148154. http://dx.doi.org/10.1007/s11130-014-0411-3. PMid:24627046.

Mošovská, S., Mikulášová, M., Brindzová, L., Valík, L., \& Mikusová, L. (2010). Genotoxic and antimutagenic activities of extracts from pseudocereals in the Salmonella mutagenicity assay. Food and Chemical Toxicology, 48(6), 1483-1487. http://dx.doi.org/10.1016/j. fct.2010.03.015. PMid:20303377.

Mukisa, I. M., Muyanja, C. M. B. K., Byaruhanga, Y. B., Schüller, R. B., Langsrud, T., \& Narvhus, J. A. (2012). Gamma irradiation of sorghum flour: Effects on microbial inactivation, amylase activity, fermentability, viscosity and starch granule structure. Radiation Physics and Chemistry, 81(3), 345-351. http://dx.doi.org/10.1016/j. radphyschem.2011.11.021.

N’Dri, D., Mazzeo, T., Zaupa, M., Ferracane, R., Fogliano, V., \& Pellegrini, N. (2013). Effect of cooking on the total antioxidant capacity and phenolic profile of some whole-meal African cereals. Journal of the Science of Food and Agriculture, 93(1), 29-36. http://dx.doi. org/10.1002/jsfa.5837. PMid:22886608.

Nguyen, P. H., Zhao, B. T., Lee, J. H., Kim, Y. H., Min, B. S., \& Woo, M. H. (2015). Isolation of benzoic and cinnamic acid derivatives from the grains of sorghum bicolor and their inhibition of lipopolysaccharideinduced nitric oxide production in RAW 264.7 cells. Food Chemistry, 168, 512-519. http://dx.doi.org/10.1016/j.foodchem.2014.06.119. PMid:25172742.
Ocheme, O. B., Oludamilola, O. O., \& Gladys, M. E. (2010). Effect of lime soaking and cooking (Nixtamalization) on the proximate, functional and some anti-nutritional properties of millet flour. $A U$ Journal of Technology, 14(2), 131-138.

Pekkinen, J., Rosa, N. N., Savolainen, O. I., Keski-Rahkonen, P., Mykkänen, H., Poutanen, K., Micard, V., \& Hanhineva, K. (2014). Disintegration of wheat aleurone structure has an impact on the bioavailability of phenolic compounds and other phytochemicals as evidenced by altered urinary metabolite profile of diet-induced obese mice. Nutrition \& Metabolism, 11(1), 1. http://dx.doi.org/10.1186/17437075-11-1. PMid:24383425.

Pengilly, C., García-Aparicio, M. P., Diedericks, D., Brienzo, M., \& Görgens, J. F. (2015). Enzymatic hydrolysis of steam-pretreated sweet sorghum bagasse by combinations of cellulase and endo-xylanase. Fuel, 154, 352-360. http://dx.doi.org/10.1016/j.fuel.2015.03.072.

Poquette, N. M., Gu, X., \& Lee, S. O. (2014). Grain sorghum muffin reduces glucose and insulin responses in men. Food \& Function, 5(5), 894-899. http://dx.doi.org/10.1039/C3FO60432B. PMid:24608948.

Pradeep, P. M., \& Sreerama, Y. N. (2015). Impact of processing on the phenolic profiles of small millets: evaluation of their antioxidant and enzyme inhibitory properties associated with hyperglycemia. Food Chemistry, 169, 455-463. http://dx.doi.org/10.1016/j. foodchem.2014.08.010. PMid:25236251.

Robin, F., Théoduloz, C., \& Srichuwong, S. (2015). Properties of extruded whole grain cereals and pseudocereals flours. International Journal of Food Science \& Technology, 50(10), 2152-2159. http://dx.doi. org/10.1111/ijfs.12893.

Rosa, N. N., Dufour, C., Lullien-Pellerin, V., \& Micard, V. (2013). Exposure or release of ferulic acid from wheat aleurone : Impact on its antioxidant capacity. Food Chemistry, 141(3), 2355-2362. http://dx.doi.org/10.1016/j.foodchem.2013.04.132. PMid:23870968.

Rose, D. J., \& Inglett, G. E. (2010a). Production of feruloylated arabinoxylooligosaccharides from maize (Zea mays) bran by microwave-assisted autohydrolysis. Food Chemistry, 119(4), 1613-1618. http://dx.doi. org/10.1016/j.foodchem.2009.09.053.

Rose, D. J., \& Inglett, G. E. (2010b). Two-stage hydrothermal processing of wheat (triticum aestivum) bran for the production of feruloylated arabinoxylooligosaccharides. Journal of Agricultural and Food Chemistry, 58(10), 6427-6432. http://dx.doi.org/10.1021/jf100058v. PMid:20408584.

Rudra, S. G., Jakhar, N., Nishad, J., Saini, N., Sen, S., Bhardhwaj, R., Jaiswal, S., Suneja, P., Singh, S., \& Kaur, C. (2015). Extrusion conditions and antioxidant properties of sorghum, barley and horse gram based snack. Vegetos, 28(October), 171-182. http://dx.doi. org/10.5958/2229-4473.2015.00053.1.

Salawu, S. O., Bester, M. J., \& Duodu, K. G. (2014). Phenolic composition and bioactive properties of cell wall preparations and whole grains of selected cereals and legumes. Journal of Food Biochemistry, 38(1), 62-72. http://dx.doi.org/10.1111/jfbc.12026.

Salazar Lopez, N. J., Loarca-Piña, G., Campos-Vega, R., Gaytán Martínez, M., Morales Sánchez, E., Esquerra-Brauer, J. M., Gonzalez-Aguilar, G. A., \& Robles Sánchez, M. (2016). The extrusion process as an alternative for improving the biological potential of sorghum bran: phenolic compounds and antiradical and anti-Inflammatory capacity. Evidence-Based Complementary and Alternative Medicine, 2016(1), 8387975. http://dx.doi.org/10.1155/2016/8387975. PMid:27738445.

Shin, H., Mcclendon, S., Le, T., Taylor, F., \& Chen, R. R. (2006). A complete enzymatic recovery of ferulic acid from corn residues with extracellular enzymes from Neosartorya spinosa NRRL185. Biotechnology and Bioengineering, 95(6), 1108-1115. http://dx.doi. org/10.1002/bit.21056. PMid:16917955. 
Singh, S., Gamlath, S., \& Wakeling, L. (2007). Nutritional aspects of food extrusion: a review. International Journal of Food Science \& Technology, 42(8), 916-929. http://dx.doi.org/10.1111/j.13652621.2006.01309.x.

Stefoska-Needham, A., Beck, E. J., Johnson, S. K., \& Tapsell, L. C. (2015). Sorghum: an underutilized cereal whole grain with the potential to assist in the prevention of chronic disease. Food Reviews International, 31(4), 401-437. http://dx.doi.org/10.1080/87559129.2015.1022832.

Svensson, L., Sekwati-Monang, B., Lutz, D. L., Schieber, A., \& Ganzle, M. G. (2010). Phenolic acids and flavonoids in nonfermented and fermented Red sorghum (Sorghum bicolor L. Moench). Journal of Agricultural and Food Chemistry, 58(16), 9214-9220. http://dx.doi. org/10.1021/jf101504v. PMid:20677784.

Food and Agriculture Organization Corporate Statistical Database FAOSTAT. (2017). The food and agriculture organization corporate statistical database. Rome: Faostat.

Tiwari, P., Kumar, B., Mandeep, K., Kaur, G., \& Kaur, H. (2011). Phytochemical screening and extraction: a review. Internationale Pharmaceutica Sciencia, 1(1), 98-106.

Towo, E., Matuschek, E., \& Svanberg, U. (2006). Fermentation and enzyme treatment of tannin sorghum gruels: effects on phenolic compounds, phytate and in vitro accessible iron. Food Chemistry, 94(3), 369-376. http://dx.doi.org/10.1016/j.foodchem.2004.11.027.

Uraji, M., Kimura, M., Inoue, Y., Kawakami, K., Kumagai, Y., Harazono, K., \& Hatanaka, T. (2013). Enzymatic production of ferulic acid from defatted rice bran by using a combination of bacterial enzymes. Applied Biochemistry and Biotechnology, 171(5), 1085-1093. http:// dx.doi.org/10.1007/s12010-013-0190-6. PMid:23512135.

Vargas-Solórzano, J. W., Carvalho, C. W. P., Takeiti, C. Y., Ascheri, J. L. R., \& Queiroz, V. A. V. (2014). Physicochemical properties of expanded extrudates from colored sorghum genotypes. Food Research International, 55, 37-44. http://dx.doi.org/10.1016/j. foodres.2013.10.023.

Verma, B., Hucl, P., \& Chibbar, R. N. (2009). Phenolic acid composition and antioxidant capacity of acid and alkali hydrolysed wheat bran fractions. Food Chemistry, 116(4), 947-954. http://dx.doi.org/10.1016/j. foodchem.2009.03.060.

Vilakati, N., Taylor, J. R. N., Macintyre, U., \& Kruger, J. (2016). Effects of processing and addition of a cowpea leaf relish on the iron and zinc nutritive value of a ready-to-eat sorghum-cowpea porridge aimed at young children. Lebensmittel-Wissenschaft + Technologie, 73, 467-472. http://dx.doi.org/10.1016/j.lwt.2016.06.022.
Volf, I., Ignat, I., Neamtu, M., \& Popa, V. I. (2014). Thermal stability, antioxidant activity, and photo-oxidation of natural polyphenols. Chemical Papers, 68(1), 121-129. http://dx.doi.org/10.2478/s11696013-0417-6.

Wang, T., He, F., \& Chen, G. (2014). Improving bioaccessibility and bioavailability of phenolic compounds in cereal grains through processing technologies: A concise review. Journal of Functional Foods, 7(1), 101-111. http://dx.doi.org/10.1016/j.jff.2014.01.033.

Wu, G., Johnson, S. K., Bornman, J. F., Bennett, S. J., \& Fang, Z. (2017). Changes in whole grain polyphenols and antioxidant activity of six sorghum genotypes under different irrigation treatments. Food Chemistry, 214, 199-207. http://dx.doi.org/10.1016/j.foodchem.2016.07.089. PMid:27507466.

Wu, L., Huang, Z., Qin, P., \& Ren, G. (2013). Effects of processing on phytochemical profiles and biological activities for production of sorghum tea. Food Research International, 53(2), 678-685. http:// dx.doi.org/10.1016/j.foodres.2012.07.062.

Xu, J. G., Tian, C. R., Hu, Q. P., Luo, J. Y., Wang, X. D., \& Tian, X. D. (2009). Dynamic changes in phenolic compounds and antioxidant activity in oats (Avena nuda L.) during steeping and germination. Journal of Agricultural and Food Chemistry, 57(21), 10392-10398. http://dx.doi.org/10.1021/jf902778j. PMid:19827789.

Yan, S., Wu, X., Dahlberg, J., Bean, S. R., Macritchie, F., Wilson, J. D., \& Wang, D. (2010). Properties of field-sprouted sorghum and its performance in ethanol. Journal of Cereal Science, 51(3), 374-380. http://dx.doi.org/10.1016/j.jcs.2009.12.006.

Yang, L., Allred, K. F., Geera, B., Allred, C. D., \& Awika, J. M. (2012). Sorghum phenolics demonstrate estrogenic action and induce apoptosis in nonmalignant colonocytes. Nutrition and Cancer, 64(3), 419-427. http://dx.doi.org/10.1080/01635581.2012.657333 . PMid:22369068.

Yousif, A., Nhepera, D., \& Johnson, S. (2012). Influence of sorghum flour addition on flat bread in vitro starch digestibility, antioxidant capacity and consumer acceptability. Food Chemistry, 134(2), 880-887. http://dx.doi.org/10.1016/j.foodchem.2012.02.199. PMid:23107703.

Zaroug, M., Orhan, I. E., Senol, F. S., \& Yagi, S. (2014). Comparative antioxidant activity appraisal of traditional Sudanese kisra prepared from two sorghum cultivars. Food Chemistry, 156, 110-116. http:// dx.doi.org/10.1016/j.foodchem.2014.01.069. PMid:24629945.

Zori, Z., Dragovi, V., Pedisi, S., \& Garofuli, I. E. (2014). Kinetics of the degradation of anthocyanins, phenolic acids and flavonols during heat treatments of freeze-dried sour cherry marasca paste. Food Technology and Biotechnology, 52(1), 101-108. 